Using the rate of clearance of sputum purulence and rate of improvement of $x$-ray inflammatory change as an index of clinical response, the results of this study show that routine bacteriological examination of sputum is of no value. Almost all patients responded to a single course of antibiotic treatment which was chosen using clinical criteria only. The vast majority of patients with exacerbations of chronic bronchitis can and should be managed without routine bacteriological control. Sputum need be examined in the laboratory only if it remains purulent after seven days of antibiotic treatment, but even then clinically misleading results may be obtained. Exceptions to this practice should be made, of course, when, from the history, clinical findings, or chest $x$-ray appearances, it is strongly suspected that an unusual organism is present.

(Accepted 15 May 1978)

Respiratory Unit, Northern General Hospital, Edinburgh

I C PATERSON, MRCP, senior registrar

G R PETRIE, MRCP, registrar

G K CROMPTON, FRCPE, consultant physician

Victoria Hospital, Kirkcaldy

J R ROBERTSON, MB, СHB, registrar

\section{Search for late-onset side effects of practolol}

Side effects of practolol, such as the oculomucocutaneous syndrome, ${ }^{1}$ are well recognised. Many occur during treatment but pulmonary complications may appear 20 months after stopping practolol. ${ }^{2}$ We have therefore reviewed for late-onset side effects all patients at the Glasgow Blood Pressure Clinic ever given practolol.

\section{Patients, methods, and results}

The patients were all those treated at the clinic. Clinical and therapeutic details were documented on proformas and stored in a KDF9 digital computer. ${ }^{3}$ By using an extract programme, we identified patients who had taken practolol for more than one month for review. Investigations included: clinical and ophthalmological examination, full blood count and ESR; urea and electrolyte concentrations; liver function tests, chest $x$-ray film; electrocardiograph; antinuclear factor (ANF) and indirect immunofluorescence studies. Ophthalmological assessment included visual acuity, slit-lamp examination, Schirmer's test, and Rose Bengal dye test. Intercellular antibody was searched for by the $\mathrm{Amos}^{4}$ technique, using baboon oesophagus as substrate.

Of the 59 patients identified, six had died, 17 had received practolol for less than one month, and five were untraceable. Thirty-one, 15 women and 16 men, were reviewed (see table). Three had died of myocardial infarction and three of stroke. Postmortem confirmation was available in four. There was no suggestion of late-onset toxicity in their records. Examination of the survivors showed no pericarditis, sclerosing peritonitis, or systemic lupus syndrome.

Three patients had histories of probable practolol toxicity rashes.

Case 1-A 44-year-old man had persisting eczema on his hands which had appeared during practolol treatment.

Case 2-A 54-year-old woman had developed severe nummular eczema while taking practolol. This had cleared after stopping it.

Case 3-A 40-year-old man had developed a persisting psoriatic rash on his thighs during treatment with practolol.

Case 4-Serous otitis media developed after two years in a 66-year-old woman treated from May 1969 to November 1974. This persists.

Three patients had opthalmological complaints but none of these could be related to practolol.

Dose and duration (mean and range) of practolol treatment in 31 hypertensive patients who were reviewed

\begin{tabular}{|c|c|c|c|c|}
\hline & & Patients: & 16 men & 15 women \\
\hline $\begin{array}{l}\text { Age (years) . . } \\
\text { Dosage of practolol (mg) } \\
\text { Time on practolol (months) } \\
\text { Time off practolol (months) }\end{array}$ & $\begin{array}{ll}\cdots & \cdots \\
\cdots & \cdots \\
\cdots & \cdots\end{array}$ & $\begin{array}{l}. \\
\because \\
\because\end{array}$ & $\begin{array}{l}56 \\
400 \\
16 \cdot 5 \\
44\end{array}$ & $\begin{array}{c}42-65 \\
100-2000 \\
3-66 \\
18-92\end{array}$ \\
\hline
\end{tabular}

Case 5-A 53-year-old man had recurrent corneal erosions, starting three years after stopping practolol.

Case 6-A 54-year-old man had grittiness of both eyes starting four years after stopping practolol. The result of examination was normal.

Case 7-A 58-year-old man with rheumatoid arthritis had signs of keratoconjunctivitis sica.

The results of all routine investigations were normal other than in one patient with active rheumatoid arthritis who had a raised ESR and anaemia. ANF was detected in three women and two men, the titres being $1 / 16$ in two, $1 / 64$ in one, and $1 / 256$ in two. Intercellular antibody was not detected in any of the 31 patients.

\section{Comment}

Because of the serious nature of practolol toxicity we decided to review all exposed patients and to look particularly for late-onset consequences. Computerised records were essential for this study, providing prompt and accurate identification of the patients at risk. The study identified three patients known to have probable practolol toxicity and one other patient with chronic serous otitis media in whom the link with practolol treatment had been unrecognised.

$\mathrm{Amos}^{4}$ has suggested that intercellular antibody is a sensitive index of practolol toxicity, but it was not found in this study. ANF was present in low titres in $16^{\circ}$ of the patients and none of these showed any evidence of toxicity. This frequency of detectable ANF was little different from the $10-14^{\circ}{ }_{0}$ expected in healthy subjects. ${ }^{5}$

In conclusion, this review of patients who received practolol showed no late-onset toxicity. Though this result is reassuring, continued vigilance may be required.

We thank Dr J J Brown, Dr G J Addis, Dr M Ramsay, and Mrs E Adams for their valuable help.

Requests for reprints should be addressed to JB.

1 Wright, P, British Medical fournal, 1975, 1, 595

2 Marshall, A J, et al, Lancet, 1977, 2, 1254.

3 The Glasgow Blood Pressure Clinic, fournal of the Royal College of Physicians of London, 1972, 7, 87.

${ }^{4}$ Amos, H E, Brigden, W D, and McKerron, R A, British Medical fournal, $1975,1,598$.

${ }^{5}$ MacSween, R N M, personal communication, 1977.

(Accepted 5 fune 1978)

Stobhill General Hospital, Glasgow

J BARCLAY, MB, MRCP, registrar in medicine

Western Infirmary, Glasgow

L E RAMSAY, MB, MRCP, lecturer in medicine

J L JAY, BSC, FRCS, consultant in ophthalmology

A MCQUEEN, MB, MRCPATH, senior lecturer in dermatological pathology

Glasgow Royal Infirmary

A R LORIMER, MD, FRCP, consultant cardiologist

\section{Legionnaires' disease and acute renal failure}

Legionnaires' disease was named after an outbreak of 182 cases at the American Legion conference in $1976 .^{1-3}$ It is now apparent that the infecting organism had been responsible for previous outbreaks of pneumonia. ${ }^{23}$ One of these affected holidaymakers from Glasgow who visited Benidorm in $1973 .{ }^{4}$ A television broadcast on this episode interested one of our patients; he had contracted pneumonia while in the same Spanish hotel four years later and drew the fact to our attention.

\section{Case report}

A 66-year-old man had been treated for myxoedema due to autoimmune thyroiditis in 1973 but had stopped taking his thyroxine in 1976 . He smoked 20 cigarettes a day and had three "colds on the chest" each year with wheezing but no dyspnoea or cough between attacks. In May 1977 he took two weeks' 